\title{
DRYING BEHAVIOR OF PEANUTS USING A ROTARY DRYER
}

Tayel, S. ${ }^{(1)}$; Ghanem, T. $^{(2)}$; EI - Kholy, M. M. ${ }^{(3)}$ \& Hamad, T. O. ${ }^{(4)}$

\section{ABSTRACT}

A study was carried out to test and evaluate high-temperature short-time drying behavior of peanuts pods using a laboratory scale rotary dryer. The experimental work was conducted at six different levels of cylinder surface temperature 55, 65, 75, 85, 95 and $105^{\circ} \mathrm{C}$, three levels of cylinder rotational speed 3, 6 and 9 (r.p.m) and three peanut batch masses 1, 1.5 and 2 (kg/batch). The high temperature rotary drier was evaluated in terms of operating factors likewise moisture regiem, drying temperature, pods and kernels temperatures, batch mass feed, cylinder rotational speed and compatibility of experimental data to Lewis models. The optimal treatment of the high temperatur dried pods of peanuts was slected in terms of physical characteristics of microbiological quality parameters, percentages of broken, splitted, shriveled kernels, oil content of peanuts, free fatty acids and peroxide value of peanuts oil. The results show that, heating surface temperature of $65^{\circ} \mathrm{C}$, cylinder rotational speed of 6 r.p.m and pods batch mass of $1.5 \mathrm{~kg}$ recorded the lowest values of kernels splitting, broken and shriveling percentages. The mathematical analysis showed that, Lewis model could satisfactorily describe the drying behavior of high moisture peanuts pods.

\section{INTRODUCTION}

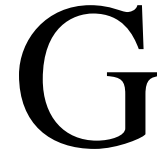
roundnut had been cultivated by ancient Egyptian science 5000 years ago. It is considers the most important protein-rich and it occupies the fifth position as oilseed crop globally after soybean, cottonseed, rape seed, and sunflower seed (Charjan et al., 1992). It is grown as annual crop on about 19million hectares of land in tropical regions and the warmer areas of temperate regions of the world. In Egypt, groundnut cultivated area was about 150767 feddans yearly producing about 1.36 ton/feddan (Oil Seed Situation \& Oulbook,2002).

(1), (2) Professor of Agric. Eng. Fac of Agric. Eng. Al-Azhar Univ.

(3) Deputy Director, Agric. Eng. Res. Institute

(4) PhD student, Fac of Agric. Eng. Al- Azahar Univ. 
Peanuts pods are typically dried using sun drying method. The disadvantages of this method associated with, the process is slow and insects and dust get mixed with the product. Meanwhile, the convective drying process is normally not able to kill the insects and fungi in infested pods due to the relatively low air temperature. Accelerated drying of high moisture peanuts as a method of drying and conditioning has been tried by different investigators (Athapol, 1994; Abd ElReheem, 2013 and Mohamed, 2014). There is evidence in literature that conduction heating of high moisture peanuts using high temperature short time, could be beneficial in terms of rapid drying, improved kernels quality and possible destruction of microorganisms. The present study aims to test and evaluate the drying characteristics of high-temperature short time conduction heating technique for drying high moisture peanuts pods. In addition, the effects of heating treatment on kernels and oil quality were also investigated.

\section{MATERIALS AND METHODS}

Freshly harvested peanut pods variety (Giza-5) were used for the experimental work. The harvesting process of peanut pods was executed manually at initial moisture content of about $63 \pm 0.5 \%$ (d.b). The experimental work was conducted at the laboratory of the Agricultural Engineering Research Institute, Dokki- Giza. Broken pods and other impurities were discarded from the harvested peanuts. The cleaned samples were stored in a deepfreezer adjusted at $-5 \pm 1{ }^{\circ} \mathrm{C}$ to prevent moisture loss and fungal growth.

\section{The accelerated rotary dryer (Conduction Heating):}

The accelerated rotary dryer fig. (1) was fabricated. The dryer consists of a rotary cylinder $(0.6 \mathrm{~m}$ in diameter and a $0.2 \mathrm{~m}$ long $)$ made of $\mathrm{I} \mathrm{mm}$ galvanized iron steel sheet enclosed by a fixed insulated cylinder $(0.8 \mathrm{~m}$ in diameter and $0.3 \mathrm{~m}$ long). One side of the rotary cylinder connected to a driving mechanism consists of a $150 \mathrm{~mm}$ diameter steel flange fixed to the side cover of the rotary cylinder and welded to a steel bar riding into a heavy duty ball bearing. A $0.5 \mathrm{~kW}$ low speed motor with different sizes of pulleys was used for power supply and speed control of the rotary cylinder. The other side of the rotary cylinder used as an inlet for peanuts 
seeds samples through a $0.15 \mathrm{~m}$ diameter center hole. The heat treated peanut pods discharged through a perforated removable sector of the cylinder bottom. For heating and temperature control of the rotary cylinder surface, two $\mathrm{kW}$ electric resistance heater were placed at the inner surface of the fixed insulated cylinder (between the rotary cylinder and the insulated exterior cylinder)

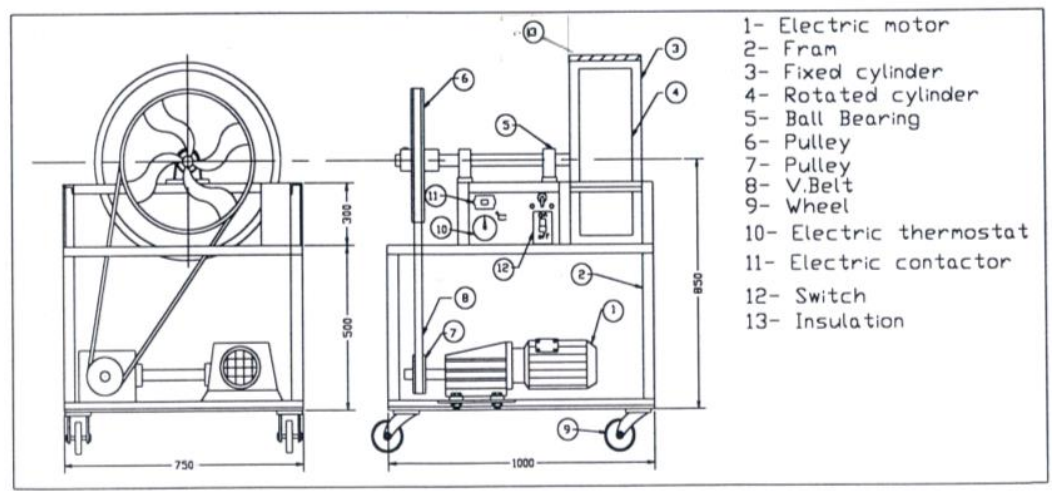

Fig. (1): Schematic diagram of the accelerated rotary dryer

\section{Experimental treatments:}

High temperature short time drying technique (HTST) was applied under six different levels of heating surface temperatures $(55,65,75,85,95$, 105 and $\left.115^{\circ} \mathrm{C}\right)$ three different peanuts batch mass (1, 1.5 and 2 $\mathrm{Kg} / \mathrm{batch}$ ) and three different levels of cylinder rotational speeds (3- 6and $9 \mathrm{rpm})$.

\section{Test procedure;}

Before runing each experiment, peanut samples were taken out from the freezer and lefted until the initial temperature of pods approached a level equal to that of room temperature. Following this, the samples were kept at insulated container in order to maintain the uniformity of the initial pods temperature during the experimental work. Prior to each experimental run, a dummy sample was used and the temperature of the cylinder surface was adjusted at the required level. When the surface temperature of the rotary cylinder became stable, the dummy sample was discharged and replaced by the testing sample. Drying runs started after the required heating surface temperature of the dryer was attained and continuoued until reaching the recommended final moister content of 
peanuts pods. The final moisture content was assessed through a periodical sub-runs at 10 mins interval time. The heated pods were cooled to room temperature in a wooden box covered with a perforated aluminum foil to allow gradual cooling with escape of vapor during the cooling process, before measurement of pods moisture content at the end of each sub-run, each experiment the heat treated pods were divided into three sub samples, $300 \mathrm{~g}$ each, the first one used for fungal colony count, the second was used to determine pods moisture content, while the third one was used for quality evaluation tests.

\section{Measurements:}

\section{Surface temperature measurement of the dryer rotary cylinder:}

The remote-type infra red spot thermometer model (HT-11) was used to measure the rotary cylinder surface temperature. The emissive of the thermometer was adjusted at 0.85 for iron sheet surfaces and the temperature was measured at different points, allover the cylinder surface.

\section{Bulk temperature of the heat-treated peanut pods and seeds:}

The bulk temperature of peanut pods and the temperature of peanut kernals were immediately measured at the end of each experimental run. The discharged pods from the rotary cylinder were received in an insulated glass vessel and the sensing prop of a one point temperature meter model (A.W. SPERRY DM-8600) with range of 0 to $400^{\circ} \mathrm{C}$ and accuracy of $\pm 0.5{ }^{\circ} \mathrm{C}$ was inserted in the sample bulk until reaching a constant reading for measuring the kernels temperature, a one point temperature meter model (T.M-2005) was used. Teh meter thermocouple type (T) was inserted through the kernel using an iron neddle. For measuring the kernel temperature with accurancy of $0.01{ }^{\circ} \mathrm{C}$.

\section{Moisture content of peanut pods:}

For measuring the moisture contents of peanuts pods before and after the drying process an electric oven was used according to ASAE methods (2003).

Percent Shells (A).

$$
A=\frac{100(\text { Initial Mass of Shells })}{(\text { Initial Mass of Pods })}
$$


Percent Kernels (B).

$$
B=\frac{100(\text { Initial Mass of Kernels })}{(\text { Initial Mass of Pods })} .
$$

Moisture content of shells, percent wet basis (C).

$$
C=\frac{100(\text { Loss in Mass of Shells })}{(\text { Initial Massof Shells })} \text {. }
$$

Moisture content of kernels, percent wet basis (D).

$$
D=\frac{100(\text { Loss in Mass of Kernels })}{(\text { Initial Mass of Kernels })}
$$

Moisture content of whole pods, percent wet basis (E).

$$
E=\frac{D(B)+C(A)}{100}
$$

The moisture contents were converted to dry basis using the following equation:

$$
M . c(d . b) \%=\frac{M . c(w . b)}{100-M \cdot c(w \cdot b)} \times 100
$$

\section{Quality evaluation tests}

\section{Percentage of broken kernels:}

Breakage of the dried peanuts was evaluated by the method of Wyne (1982). Dried peanut samples were manually shelled using a manually operated peanut sheller. The obtained peanuts were separated into unshelled pod $\left(\mathrm{W}_{\mathrm{u}}\right)$, bald seeds (kernels broken into halves) $\left(\mathrm{W}_{\mathrm{sp}}\right)$ and whole seeds $\left(\mathrm{W}_{\mathrm{b}}\right)$. All fractions were weighed in grams. Peanuts remaining in the sheller were removed and weighed $\left(\mathrm{W}_{\mathrm{c}}\right)$. percentage of broken kernels was computed by the following.

$$
\left.\mathrm{B}_{\mathrm{r}}(\%)=\left[\mathrm{W}_{\mathrm{b}}+\mathrm{W}_{\mathrm{sp}}\right) / \mathrm{W}_{\mathrm{s}}\right] \times 100 .
$$

Where: $\mathrm{W}_{\mathrm{s}}=1000-\left(\mathrm{W}_{\mathrm{u}}+\mathrm{W}_{\mathrm{c}}\right)$

\section{Percentage of splitted kernels:}

Splitted kernels represent the kernels broken into halves. The percentage of splitted kernels was determined using the following equation: 
$\%$ Splitted kernels $k_{s p}=\frac{\text { wt of splitted Kernel }}{\text { total weight of sample }} \times 100$

\section{Fungal count:}

The spread plate method recommended by Flannigan (1977) was used to determine the change in fungal colony count of peanuts samples.

\section{Theoretical Analysis of The Drying Process:}

The simple drying equation Lewis's (1921) was examined for describing the drying behavior and predicting the change in peanut pods moisture content under the accelerated drying method. The simple drying equation written as follows:

$$
M R=\frac{M-M_{e}}{M_{o}-M_{e}}=\exp \left(-k_{s} t\right) \ldots \ldots \ldots . .(9)
$$

Where:

MR : Moisture ratio, dimensionless

M : Instantaneous pods moisture content at time t, (\%, w.b)

Me : Equilibrium moisture content. (\%,w.b)

Mo : Initial moisture content, \% (w.b.).

t : Time, $\min$

$\mathrm{k}_{\mathrm{s}} \quad$ : Drying constant, $\min ^{-1}$

There is no information available about the equilibrium moisture content of peanut pods in a temperature range of 55 to $105^{\circ} \mathrm{C}$ when the air relative humidity is very low. The peanut pods will be bone dried after prolonged heating under such condition. So the moisture ratio was approximated simply by dropping the equilibrium moisture content term and thus the ratio of instantaneous moisture content of peanut pods to its initial moisture content was used for representing seeds moisture ratio as previously reported by (EL-Kholy 1998, Yaldiz et al., 2001, Sacilic and Unal 2005).

The drying constant $\left(\mathrm{k}_{\mathrm{s}}\right)$ of the simple exponential model was obtained by applying linear regression analysis to the logarithmic value of (M/Mo) and the drying time $(\mathrm{t})$. The slope of the best fit straight line represents the value of the drying constant $\left(\mathrm{k}_{\mathrm{s}}\right)$. 


\section{RESULTS AND DISCUSSION}

\section{Change in peanuts moisture content:}

A typical plots showing the change in peanuts moisture contents as related to drying time at different levels of cylinder surface temperature, cylinder rotational speed and a pods batch mass of $1.5 \mathrm{~kg} / \mathrm{batch}$ are illustrated in Fig. (2). As shown in the figure rapid moisture removal from peanuts pods was observed particularly at higher levels of heating surface temperature and lower level of pods feed rates. This is may be attributed to the higher rate of heat transfer through the surface of peanuts pods as the cylinder surface temperature and rotational speed increased.

Meanwhile, the required drying time of peanut pods to approach the final moisture content of $\pm 9.53 \%$ d.b is depending upon cylinder surface temperature, cylinder rotational speed and peanut pods batch mass. the overall average required drying time of peanuts pods ranged from 70-125 min, $70-110 \mathrm{~min}, 65$ to $110 \mathrm{~min}, 60$ to $100 \mathrm{~min}, 55$ to $90 \mathrm{~min}, 50$ to 85 $\mathrm{min}$, and from 35 to $75 \mathrm{~min}$. for the heating surface temperature of 55 , $65,75,85,95$ and $105^{\circ} \mathrm{C}$ respectively.

\section{Temperature of peanuts pods and kernels;}

A typical plot showing the change in peanuts pods bulk temperature and kernels temperature as related to drying time at different heating surface temperature, cylinder rotational speed of $6 \mathrm{rpm}$ and peanuts feed rates of 1.5 $\mathrm{kg}$ / batch is illustrated in Fig. (3). It is clear that the pods bulk temperature and the kernels temperature were lower during the early stage of heating process and it was increased with longer exposure duration. For all levels of heating surface temperature, as the exposure time increased the peanuts pods and kernels temperature increased at different rates depending upon the cylinder rotational speed and peanuts batch mass. The overall average recorded pods bulk temperature ranged from 40.13 to $43.05{ }^{\circ} \mathrm{C}, 43.18$ to $48.99{ }^{\circ} \mathrm{C}, 45.10$ to $52.08{ }^{\circ} \mathrm{C}, 50.32$ to $55.87{ }^{\circ} \mathrm{C}, 59.3$ to $61.9{ }^{\circ} \mathrm{C}$ and 60.17 to $67.27^{\circ} \mathrm{C}$ at cylinder surface temperatures of $55,65,75,85,95$, and $105{ }^{\circ} \mathrm{C}$ respectively. The corresponding values for kernels temperature ranged from 30.18 to $34.91{ }^{\circ} \mathrm{C}, 31.88$ to $36.80{ }^{\circ} \mathrm{C}, \quad 31.79{ }^{\circ} \mathrm{C}$ to 37.28 ${ }^{\circ} \mathrm{C}, 33.13$ to $37.39{ }^{\circ} \mathrm{C}, 35.20$ to 47.37 and 35.61 to $52.30{ }^{\circ} \mathrm{C}$ respectively. It should be mentioned that the kernels temperature over $40{ }^{\circ} \mathrm{C}$ may cause a severe reduction in quality of the dried peanuts as mentioned by (Athapol et. al, 1994). 

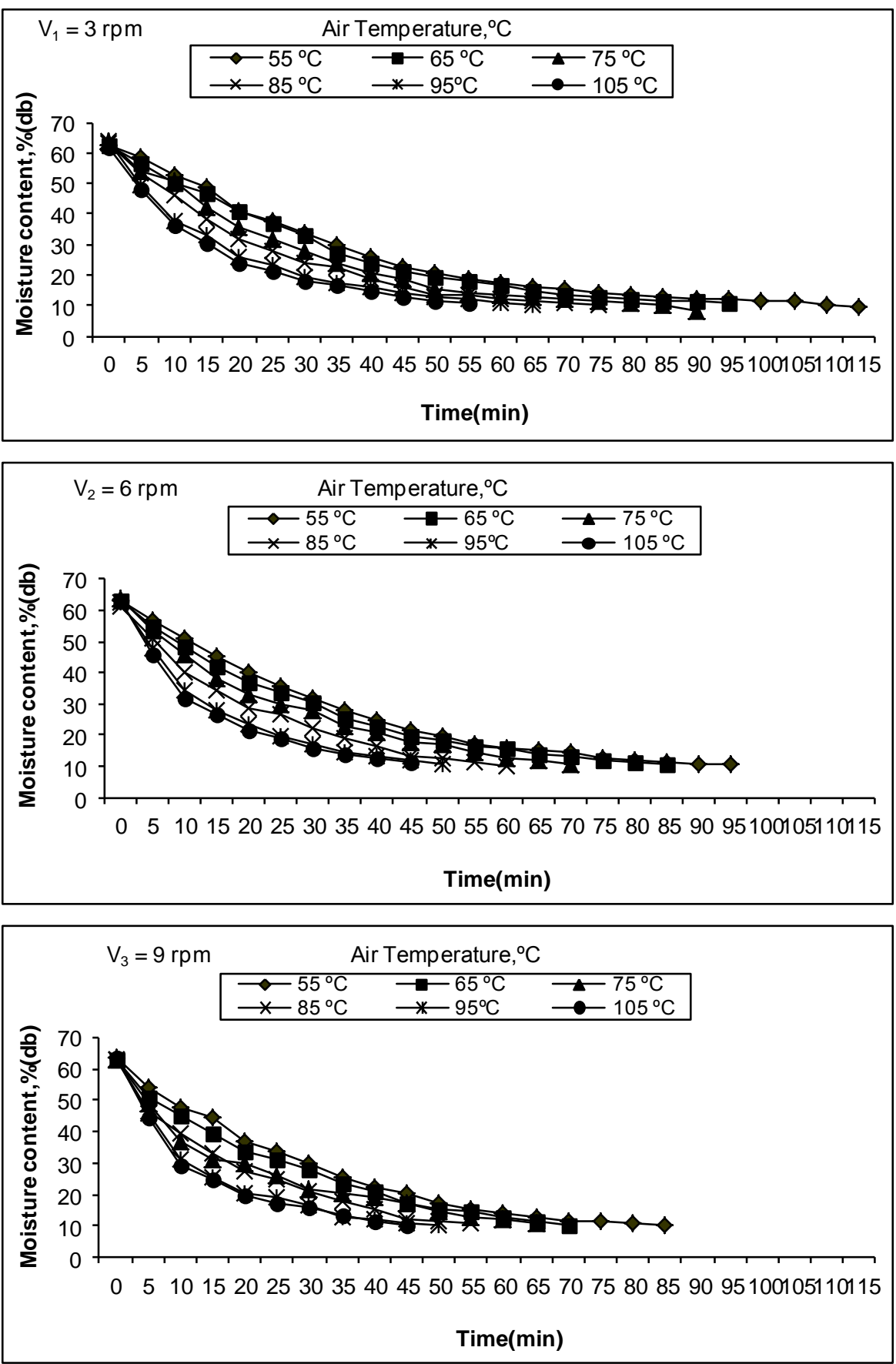

Fig. (2): Change in moisture content of peanuts pods as related to drying time at different levels of heating surface temperature, cylinder rotational speed and batch mass of $1.5 \mathrm{~kg} / \mathrm{batch}$ 


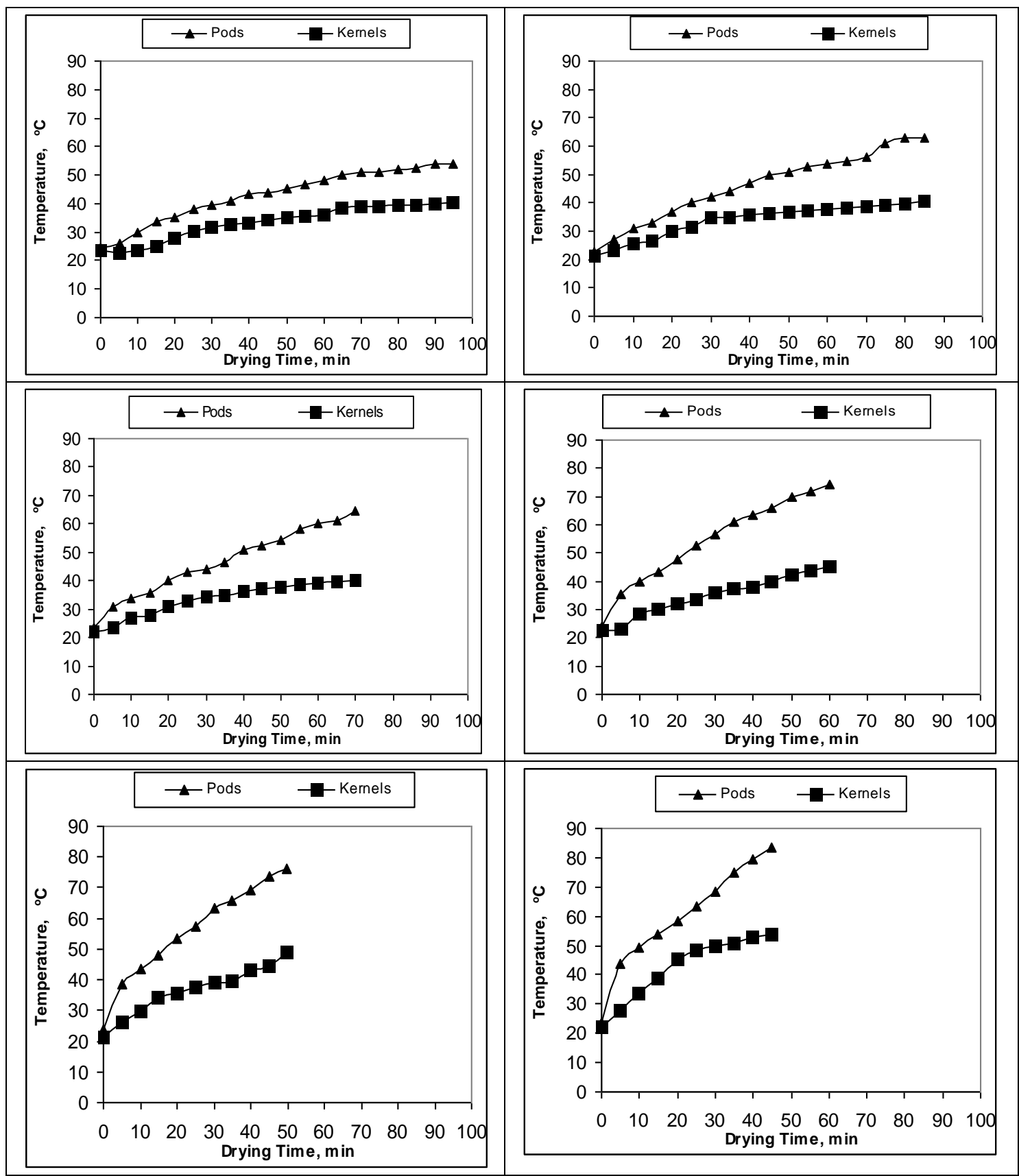

Fig. (3): A typical plot of the change in peanuts pods and kernels temperature as related to drying time at different heating surface temperature, cylinder rotational speed of $6 \mathrm{rpm}$ and peanuts batch mass of $1.5 \mathrm{Kg} / \mathrm{batch}$. 
PROCESS ENGINEERING

\section{Analysis of drying behavior during the high- temperature heating}

\section{process:}

The simple drying model (Lewis's model) was used for data analysis as follows:

$$
\begin{gathered}
M R=\exp \left(-k_{s} \boldsymbol{t}\right) \\
M R=\frac{M}{M_{o}}=e^{-k_{s} t} \quad \ldots \ldots
\end{gathered}
$$

The value of drying constants $\left(\mathrm{K}_{\mathrm{s}}\right)$ for the simple drying model were obtained from the exponential relationship between the peanuts moisture ratio (MR) and the drying time (t) as shown in Fig.(4).

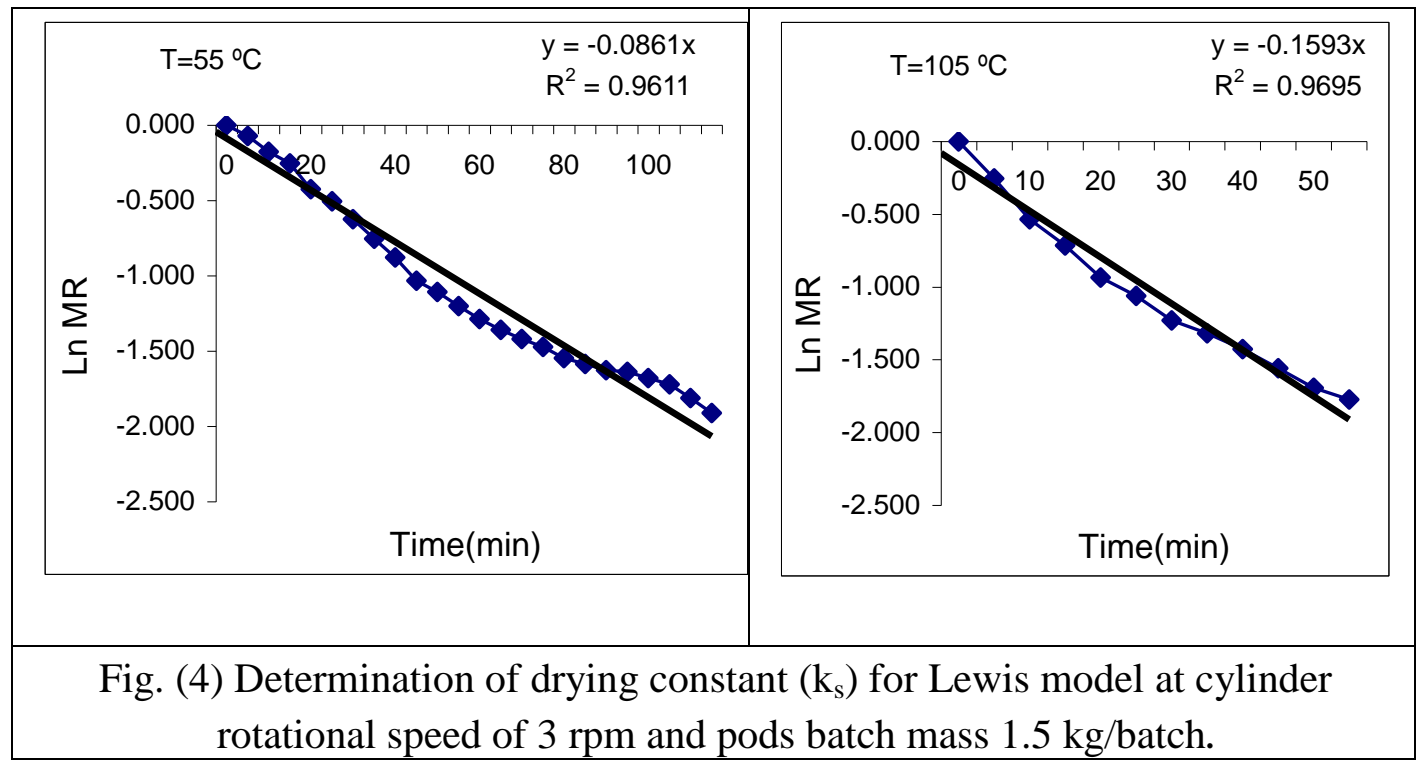

As showin fig. (5), the drying constant $\left(\mathrm{K}_{\mathrm{s}}\right)$ increased with the increase of cylinder surface temperature and cylinder rotational speed while it was decreased with the increase of batch mass. These results are in agreement with that obtained by (Mohamed et al, 2014).

A multiple regression analysis was employed to relate the experimental parameters $(\mathrm{T}) \&(\mathrm{~V}) \&\left(\mathrm{M}_{\mathrm{b}}\right)$ with the drying constant $\left(\mathrm{k}_{\mathrm{s}}\right)$. The obtained equation could be presented as follow:

$$
\mathrm{k}_{\mathrm{s}}=0.056229-0.02561\left(M_{b}\right)+0.003903(V)+0.001108(T)
$$

$\left(\mathrm{R}^{2}=0.953439\right.$ \& S.E. $\left.=0.005429\right)$ 

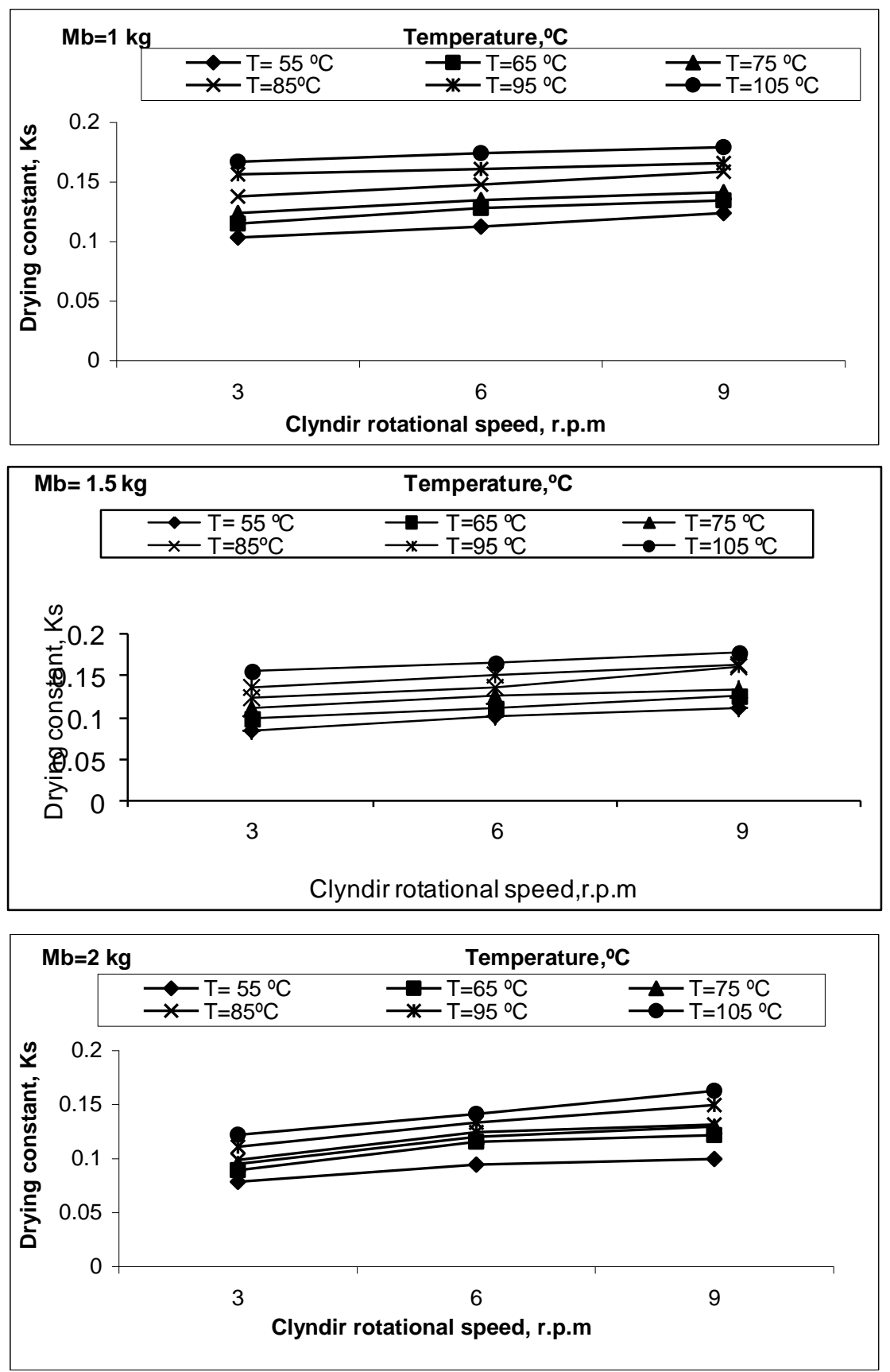

Fig. (5): Relationship between the drying constant " $\mathrm{k}_{\mathrm{s}}$ " and cylinder rotational speed "V" at different levels of heating surface temperature $(\mathrm{T})$ and peanuts batch mass $(\mathrm{Mb})$. 
PROCESS ENGINEERING

Where:

$\mathrm{K}_{\mathrm{s}} \quad=$ drying constant, $1 / \mathrm{min}$

$\mathrm{M}_{\mathrm{b}} \quad=$ batch mass fed, $\mathrm{Kg}$

$\mathrm{T}=$ Cylinder surface temperature, ${ }^{\circ} \mathrm{C}$

$\mathrm{V}=$ Cylinder rotational speed velocity, $\mathrm{rpm}$

\section{The applicability of Lewis's model in simulating the drying data:}

As shown in fig. (6) the simple drying model can be satisfactorily describe the drying behavior of peanuts pods during conduction heating process. The observed and the predicted values of peanuts moisture content at different cylinder surface temperature and the maximum levels of cylinder rotational speed and pods batch mass showed the applicability of this model in predicting the changes in peanuts moisture content during high-temperature short-time dring process.
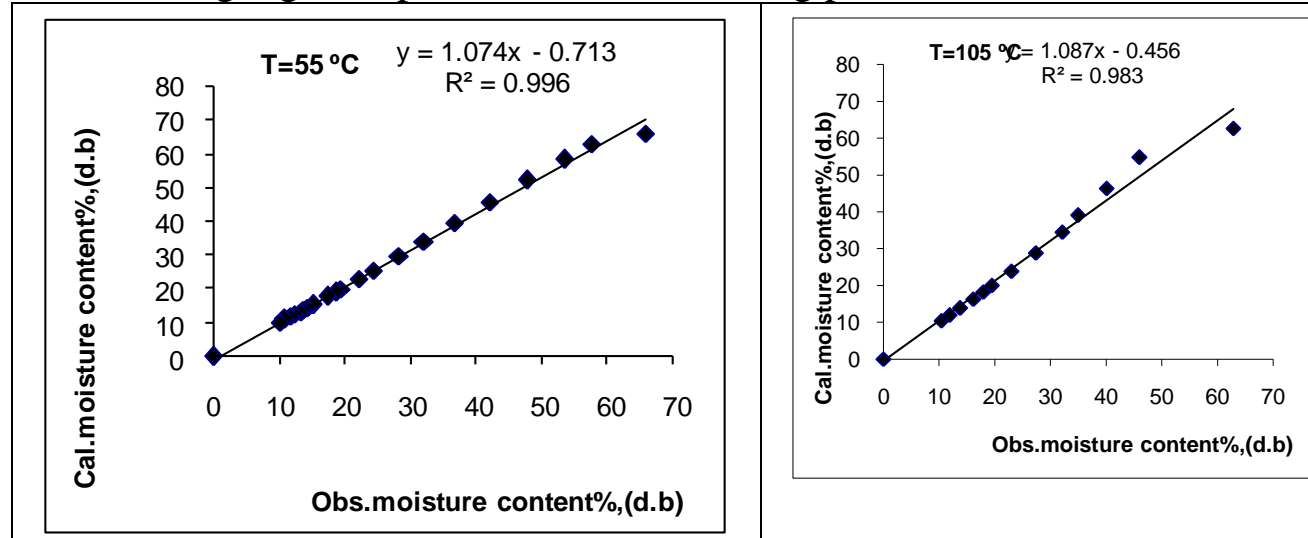

Fig. (6): The observed and calculated moisture content of peanut using the Lewis's model at the maximum cylinder rotational speed of 9 r.p.m and peanuts batch mass of $2 \mathrm{~kg} / \mathrm{batch}$.

\section{Quality analysis of peanuts after the drying process:}

\section{Fungal colony count:}

Fig. (7) presents the fungal colony count of peanut pods dried by the rotary conduction heating dryer at different pods batch mass, different heating temperature, and different cylinder rotational speeds. As shown in the figure surface, the fungal colonies count decreased with the increase of cylinder surface temperature and the cylinder rotational speed, while it was increased with the increase of pods batch mass. The 
recorded fungal count of peanut pods dried by the conduction rotary dryer ranged from 1727 to 2380 colonies/g at the minimum heating surface temperature of $55{ }^{\circ} \mathrm{C}$, while it was ranged from 111.6 to 148.3 colonies/g at the maximum heating surface temperature of $105^{\circ} \mathrm{C}$.

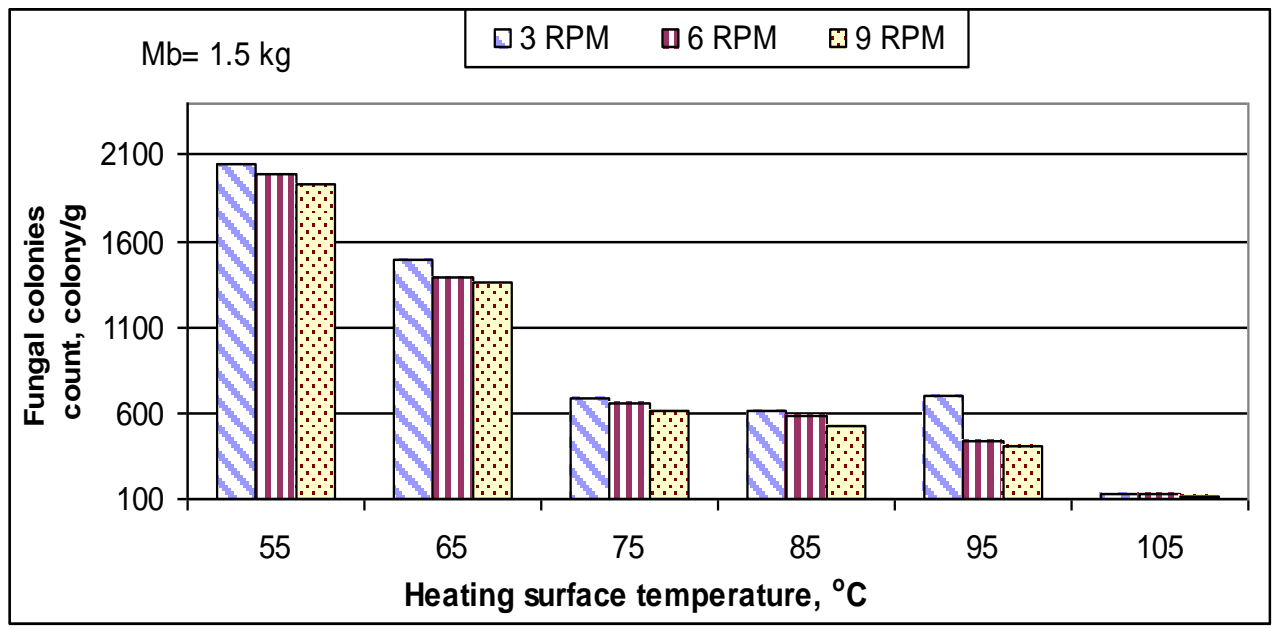

Fig. (7): Fungal colonies count of peanut pods using the conduction heating rotary dryer at differentheat surface temperature, pods batch mass of $1.5 \mathrm{~kg}$ and different cylinder rotational speed.

\section{percentage of splitted kernels:}

Fig. (8) illustrates the average values of splitted kernels as related to heating surface temperature at different levels of cylinder rotational speeds and pods batch mass. It is clear that, the percentage of splitted kernels increased with the increase of heating surface temperature, and cylinder rotational speed, while it was decreased with the increase of pods batch mass. At the minimum hating surface temperature of $55^{\circ} \mathrm{C}$, the kernel splitted percentage ranged from 5.9 to $6.5 \%$ while it was ranged from 9.03 to $11.46 \%$ at the maximum heating temperature of $105{ }^{\circ} \mathrm{C}$.

\section{Percentage of broken kernels;}

Fig. (9) illustrates the percentage of broken kernels as related to cylinder surface temperature at different studied levels of cylinder rotational speed and pods feed rate. As shown in the figure, the broken percentage increased with the increase of heating surface temperature and cylinder rotational speed, while it was varied with the batch mass rate depending upon the exposure time of kernels to the heat treatment and the resulted 
kernels bulk temperature. The recorded overall average broken percentage ranged from 7.57 to $8.97 \%, 7.53$ to $9.7 \%, 7.63$ to $8.77,8.3$ to $10.6,9.7$ to 11.2 and 10.27 to 13.67 for heating surface temperatures of $55,65,75,85,95$ and $105^{\circ} \mathrm{C}$ respectively.

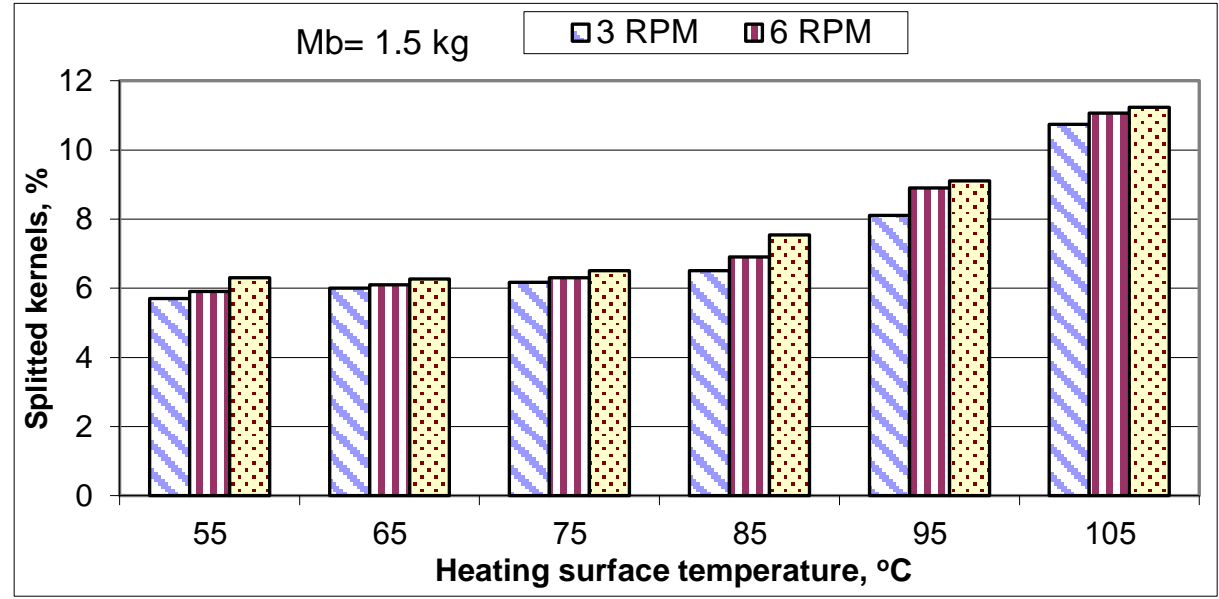

Fig.(8). Average splitted kernels of peanut pods dried at different heating surface temperature, cylinder rotational speed and pods batch mass of 1.5 $\mathrm{kg} / \mathrm{batch}$.

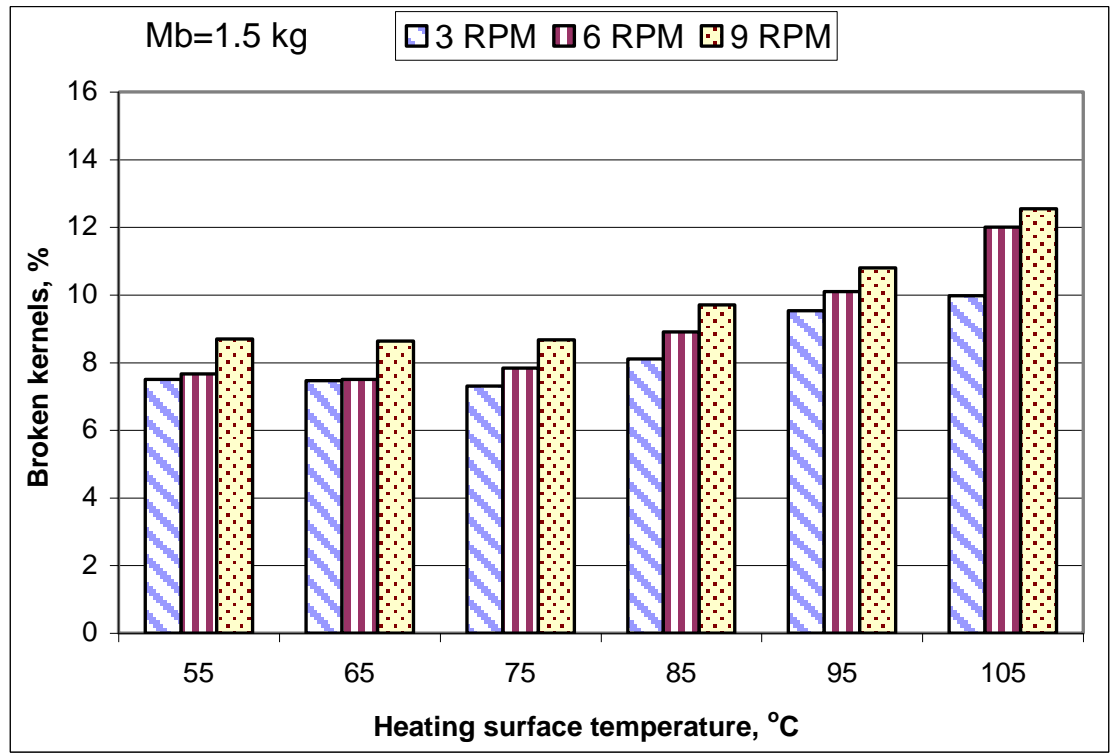

Fig. (9). Percentage of broken kernels as related to heating surface temperature at different cylinder rotational speed and pods batch mass of $1.5 \mathrm{~kg} / \mathrm{batch}$. 
PROCESS ENGINEERING

\section{CONCLUSIONS}

1- The bulk temperature of peanut pods ranged from 27.67 to $36.2{ }^{\circ} \mathrm{C}$ and the kernels temperature ranged from 21.5 to $31^{\circ} \mathrm{C}$.

2- During high- temperature drying of peanuts, rapid moisture removal from peanuts pods was obvious particularly at higher levels of heating surface temperature and lower level of pods batch mass.

3- The drying constant $\left(\mathrm{K}_{\mathrm{s}}\right)$ increased with the increase of cylinder surface temperature and cylinder rotational speed while it was decreased with the increase of batch mass.

4- The Lewis's model could satisfactory describe the drying behavior and predicting the changes in pods moisture content during the drying process.

5- Fungal colony count decreased with the increase of cylinder surface temperature and the cylinder rotational speed, while it was increased with the increase of pods batch mass.

6- The percentages of splitted and broken kernels increased with the increase of heating surface temperature, and cylinder rotational speed, while they were decreased with the increase of pods batch mass. In general, the lowest values of broken and splitted kernels were recorded at kernel bulk temperature less than $40^{\circ} \mathrm{C}$.

7- The accelerated drying of peanyts pods using high temperature rotary dryer at a cylinder surface temperature of $65^{\circ} \mathrm{C}, \quad$ cylinder rotational speed of 6 r.p.m. and pods batch mass of $1.5 \mathrm{Kg} /$ batch is recommended for rapid moisture reduction minimum fungal load, and higher quality of kernels.

\section{REFERANCES}

Abd El-Reheem, S. S. (2013). Effect of drying methods and storage environment on the quality of sunflower seeds and oil. unpublished P.hD Thesis. Dept. of Agric. Eng. Fac. of Agric Mansoura Univ.

Asae (2003) The society for Engineering in Agricultural, food, and biological systems 2950 Niles Rd., ST. Joseph, MI 49085-9659, USA ph. S410.1 FEB03. 
Athapol, N.; K. Premakumar \& H. T. Sabarez (1994). Design and Development of a conduction Drier for Accelerated Drying of Peanuts. J.of Food Engineering 21 411-419.

Charjan, S.K.U and J.L. tarar. (1992). " Influence of storage container on germinability and mycoflora of sunflower seed ( Helianthus annuus L.) seeds and farms. 1992; 18(4-6): 3-5. India.

El-Kholy, M.M, (1998). Conditioning and aeration of high moisture paddy under different storage conditions. Unpublished, Department of Agric. Eng. Fac. of Agric., Mansoura Univ.

Flannigan, B. (1977). Enumeration of fungi and assay for ability to degrade structural and components of grain. In Biodeterioration investigation techniques (ed. H. Walters) London, Applied Science Publishers, pp. 185-199.

Lewis, W. K. (1921). The rate of drying of solid materials j. of Ind. Eng.Chem. 13(5): 427-432.

Mohamed A.M.S (2014). Effect of high temperature short - time drying systems on rice milling quality. Un-published M.Sc Thesis Depe. Of Agric. Eng. Fac. Of Agric. Mansoura Univ.

Sacilic, K. and G. Unal (2005). Dehydration Characteristics of Kastamonu Garlic Slices. Bio Systems Engineering, 92: (2), 207215.

Oil seed Situation \& oullok, 2002

تقرير صادر عن قطاع الثئون الاقتصـادية بوزارة الزراعة واستصلاح الاراضس r . . r عن موقف البذور الزيتية ومستقبلها

Wyne, J.C.(1982). Variation in milling quality of peanuts. Peanuts. Peanuts Science, 9: 30-33.

Yaldiz. O.; C. Ertekin and H. L. Uum (2001). Mathematical modelling of thin laver solar drying of Sultana grapes. Energy, 26: $457-465$. 
PROCESS ENGINEERING

\section{الملخص العربي \\ سلوك التجفيف للفول السوداني باستخدام مجفف دوراني}

أ.د/ سمير طايل(') أ.د/ طارق غانم () أ.د/ محمد مصطفي الخولي() طارق عثمان حماد (؛)

تهدف الدراسة الي اختبار وتقييم استخدام درجات الحرارة المرتفعة لفترات زمنية قصيرة باستخدام مجفف دوراني يعمل بخاصية التوصيل الحراري المباثر لتجفيف قرون الفول السوداني عاليه الرطوبة بالاضافة الي قياس تاثير عملية التجفيف علي البذور المجففه كما تم ايضا اختيار نموذج Lewis's لوصف سلوك التجفيف لقرون الفول السوداني اثناء عملية التجفيف بالاضافة الي امكانية التببؤ بالمحتوي الرطوبي للقرون .ولتنفيذ التجارب المعملية_تم

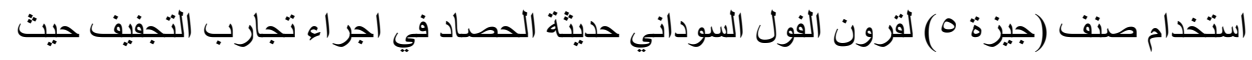

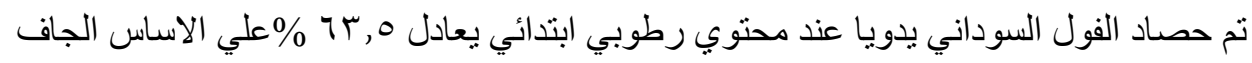

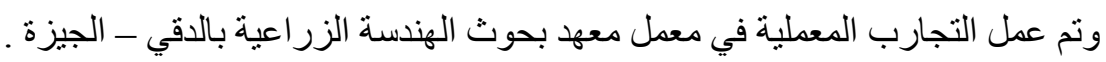
وشملت المعاملات التجريبية 7 مستويات لدرجات حرارة سطح اسطو انة التجفيف وهي (

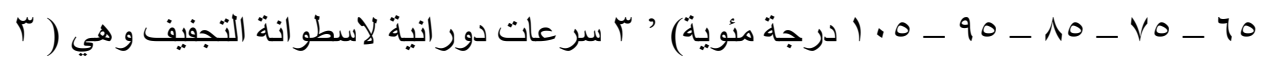

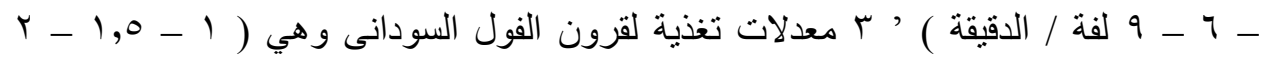
كجم/دفعة ) كما شملت القياسات المعملية درجة حرارة اسطوانة التجفيف و المحتوي الرطوبي للقرون ودرجة حرارة القرون والبذور و العد الفطري وكذلك جودة الفول السوداني المجفف بتلك الطريقة.

وكاتت أهم النتائج المتحصل عليها مايلي :

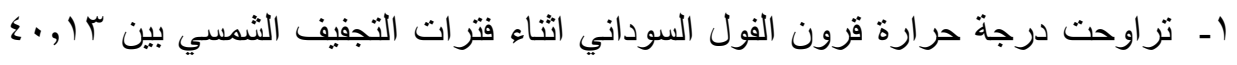

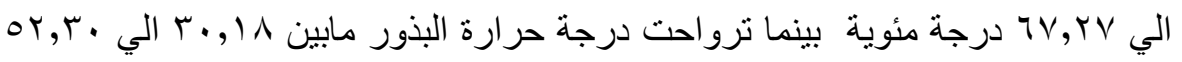

\section{درجة مئوية.}

Y- انخفض المحتوى الرطوبى لقرون الفول السوداني بطريقة سريعة أثناء عملية التجفيف باستخدام نظام التوصيل الحراري المباشر وارتفع معدل التجفيف بزيادة كلا من درجة حر ارة سطح اسطو انة التجفيف وسر عتها وكذلك انخفاض معدل التغذية للقرون. بـ أعتمد الزمن المطلوب لتجفيف قرون الفول السوداني للوصول لمحتوي رطوبي مقداره د \%,or\% 9 علي الاساس الجاف علي درجة حرارة سطح اسطوانة المجفف الدوراني

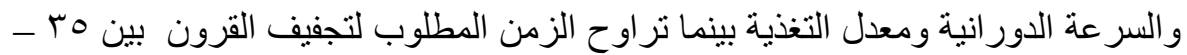

O 1 ا دقيقة .

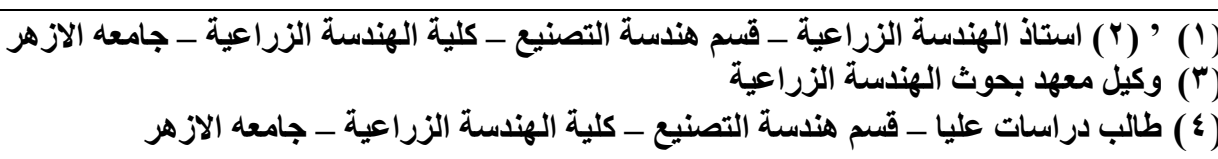


ع ـ ارتفعت قيم كلا من ثابت التجفيف Ks بزيادة درجة حرارة اسطوانة التجفيف و السرعة الدور انية لها بينما انخفضت بزيادة معدل التغذية.

○ـ نموذج Lewis's الرياضي موضوع الدراسة قد وصف سلوك التجفيف لقرون الفول

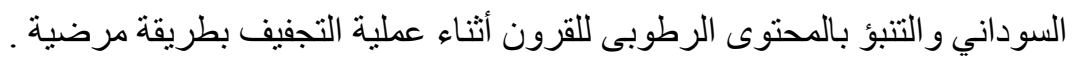

7 ـ انخفض العد الفطري للفول السودانى بزيادة درجة حر ارة سطح الاسطو انة وكذلك سر عنها الدور انية بينما ز اد بزيادة معدل التغذية.

V- ز زادت نسبة الحبوب المكسورة و المنشطره بزيادة درجة حرارة سطح اسطوانة التسخين

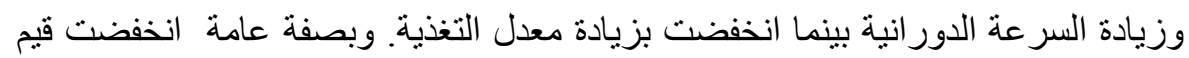

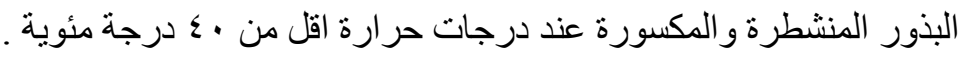

